\title{
Consistency of Teaching Media Accompanied With Instructions in Developing the Formulas of Triangle and Kite Area for Elementary School Students
}

\author{
Ketut Sarjana* \\ Mathematics Education Study Program \\ Universitas Mataram \\ Mataram, Indonesia \\ ksarjana@unram.ac.id
}

\author{
Nyoman Sridana \\ Mathematics Education Study Program \\ Universitas Mataram \\ Mataram, Indonesia
}

\begin{abstract}
It is acknowledged that elementary school students' thinking skills are within the concrete operation. As a result, teaching of geometrical concepts must be in line with their way of thinking in which students are faced with suitable physical manipulation of concrete objects. Building concepts through seeing and doing are far more effective than just listening. The concept of area is an abstract concept, so if it is presented in a concrete form, students will find it easier to understand what is being learned. Proper use of media or teaching aids could make an effective learning. The problems covered in this paper are: (1) there is no teaching aids accompanied with instructions for teaching the area of triangle and kite formulas; and (2) whether the use of teaching aids accompanied with instructions is consistent in developing the formulas for the area of triangles and kites. Therefore, the purpose of this study are: (1) to develop teaching aids accompanied with instructions for the area of triangle and kite formulas; and (2) to determine the consistency of the use of teaching aids accompanied with instructions for developing a formula for the area of triangle and kite. Two types of teaching aids accompanied with instructions dealing with the areas of the triangle and the kite have been developed. Three experts and six practitioners validated those teaching media and concluded them ready for use. In addition, after having been tried out, those teaching aids showed the effective and consistent results. This is indicated by the average scores obtained by two classes (A and B) involved, namely 81.13 and 82.06 respectively. The average scores were categorized into very high which have never been achieved before. Besides, the value of $\left|\boldsymbol{t}_{\text {count }}\right|(\mathbf{1 . 1 0 2})<\mathrm{t}$ table $(2.042)$ obtained indicated that there is no significant difference in the significant level of $5 \%$ between the average score of class $\mathrm{A}$ and $\mathrm{B}$ after learning and using those teaching aids. It can be concluded that the teaching aids accompanied with instructions used by the teacher in teaching the same material to different classes will have similar results.
\end{abstract} kite

Keywords - consistency, teaching aids, areas of triangle and

\section{INTRODUCTION}

Geometry is an abstract study. It was mentioned by Hudoyo that mathematics deals with abstract ideas, structures arranged according to logical rules [1]. This mathematical structure starts from the elements that are not defined, axioms, elements that are defined, then derived into theorem. That is why geometry is difficult to be taught according to what was revealed by the survey program for International Student Assessment 2000/2001. However, the existence of geometry studies for elementary school students can be constructed through analogy thinking results using tangible items that can be assembled or can be manipulated, because the level of thinking is still concrete.
Learning will be meaningful if the children experience or do what is learned. If students experience and do themselves about what is learned, they will have long memory. With regard to this matter, if elementary school students learn geometrical concepts or principles, they should be given the real objects or concrete things. This concrete thing is manipulated by the children to construct the concept or principle of geometry that is being studied. This is in line with statement given by Nyimas Aisyah which stated that in the learning process children should be given the opportunity to manipulate objects which are specifically designed and can be manipulated by students in understanding mathematical concepts [2]. Based on this reason, elementary school students should use teaching aids in learning geometry.

There are several reasons why the use of teaching aids is needed in learning geometry, they are: (1) The Chinese motto is quoted by Ruseffendi which states that I hear and I forget, I see, and I know, I do and I understand [3]; (2) Brunner in Russeffendi stated that in the learning process, students go through 3 stages which are enactive, iconic and symbolic; and (3) Hudoyo mentioned that learning mathematics is the process of developing mathematical concepts and principle and this is in accordance with the constructivist view.

Many researchers revealed that the use of teaching aids in learning mathematics causes learning to be more effective. One of them is Brown in Asra who stated that the media used by students or teachers can influence the effectiveness of the learning and teaching process [4]. However, this statement does not mention or explain the procedures for using the media or hew they could be carried out in order to achieve the goals.

From the above description, the problems outlined in this paper are: (1) there is no teaching aids accompanied with instructions for teaching the formulas of triangle and kite area; and (2) to what extent the use teaching aids accompanied with instructions is consistent in constructing the formulas for the area of triangle and kite. Therefore, the purposes of this study are: (1) to develop teaching aids accompanied with instructions for teaching the formulas of the area of triangle and kite; and (2) to determine the consistency of the use the teaching aids accompanied by instructions for building the formulas for the area of triangles and kites.

In this study, teaching aids made are accompanied with instructions for elementary school students. These teaching aids are seen as the real object to build the area of the triangle 
and the kite, while the instructions are made to avoid users from making mistakes. This is consistent with Bandura's statement in who observed someone's behaviour work form an understanding of how to do new behaviour, and the information that has been coded will serve as a guide for another action [5]. Because humans learn from examples, at least similar examples, before carrying out certain activities, they will avoid from making any unnecessary mistakes. In addition, it is acknowledged that learning geometry requires the use of teaching aids which means that learning geometry is influenced by factors from outside students, such as instructional media or teaching aid [6]

In terms of learning principle, activities in the use of teaching aids consist of: (1) listening, as one of the learning activities because students will listen to instructions from the teacher about what to do when utilizing the tools; (2) looking or seeing as pointing the vision to see the order, in this case, in building pieces into another shape when students work using the media; and (3) metric experimental activities in the form of cutting and building arrangements and squeezing shapes to see the relationship between shapes [7].

Among the previously relevant researches related to this study are 1) research funded by the 2007 PGSD FKIP UNRAM grant competition program which found that teaching integer through beads can improve the activities and learning achievements of the fifth-grade students at SDN 2 Mataram [8] and 2) research funded by the 2008 PGSD FKIP UNRAM grant competition program which showed that the teaching geometry of the circumference concept and the area of rectangular, triangular, parallelogram and through media can improve the learning activities and learning achievement of the fourth-grade students at SDN 40 Cakranegara [9]. However, the instructions dealing with how to use these media have not been included or put for the purpose of the operational guidelines.

\section{METHOD}

\section{A. Research type and setting}

This research employed qualitative descriptive study which study the feasibility of the developed teaching aids accompanied with the instructions, their effectiveness and consistency.

In this study, teaching aid was about developing the areas of the triangle and kite formulas for the fourth-grade elementary school students. Then, the instructions for using the device were made. To test the consistency of the teaching aid, it was tried out at the elementary school (SDN) 10 Cakranegara.

\section{B. Data Analysis Technique}

The teaching aids made were assessed and evaluated by experts and practitioners by using the questionnaire assessment dealing with the teaching aids and their instructions.

The evaluators were 3 experts in their fields and 6 senior elementary school teachers who have educator certificates and are teaching in elementary schools in Ampenan, Mataram and Cakranegara within the city of Mataram. The data collected were analyzed by using descriptive statistics with the help of SPSS 21 to find out an ideal average/mean, standard deviation and learning completeness or achievement and also to assess the consistency of teaching aid by applying t-test.

Regarding the research instrument and the qualifications achieved are set out in the following table:

TABLE 1. INSTRUMENT QUALIFICATIONS

\begin{tabular}{|l|l|l|l|}
\hline \multicolumn{1}{|c|}{ Creteria } & $\begin{array}{c}\text { Achieved } \\
\text { Qualifica } \\
\text { tions }\end{array}$ & Instrument & Source \\
\hline Appropriateness & $\begin{array}{l}\mathrm{x}>\mathrm{M}+ \\
\mathrm{SD}\end{array}$ & $\begin{array}{l}\text { Validation } \\
\text { Questionnaire }\end{array}$ & Validator \\
\hline Appropriateness & $\mathrm{x}>\mathrm{M}+$ & $\begin{array}{l}\text { Rating } \\
\text { Questionnaire }\end{array}$ & $\begin{array}{l}\text { Expert and } \\
\text { Practitioner }\end{array}$ \\
\hline Description $\mathrm{x}=$ qualified score, $\mathrm{M}=$ ideal Mean, SD = ideal \\
standard deviation
\end{tabular}

\section{RESULTS AND DISCUSSION}

\section{A. Research result}

The assessment results for the teaching aids and their instructions are presented in the following table:

TABLE 2. THE ASSESSMENT RESULTS OF THE TEACHING AIDS AND THEIR INSTRUCTIONS

\begin{tabular}{|c|c|c|c|c|c|}
\hline \multirow{2}{*}{ No. } & \multicolumn{2}{|c|}{$\begin{array}{c}\text { Teaching } \\
\text { Aids Scores }\end{array}$} & $\begin{array}{c}\text { Instructions } \\
\text { for Teaching } \\
\text { Aids scores }\end{array}$ & \multirow{2}{*}{ Category } \\
\cline { 2 - 5 } & AT & AK & AT & AK & \\
\hline 1 & 108 & 108 & 43 & 44 & Approved \\
\hline 2 & 93 & 98 & 39 & 40 & Approved \\
\hline 3 & 104 & 102 & 43 & 44 & Approved \\
\hline 4 & 107 & 110 & 44 & 45 & Approved \\
\hline 5 & 110 & 110 & 45 & 45 & Approved \\
\hline 6 & 108 & 108 & 43 & 45 & Approved \\
\hline 7 & 108 & 109 & 45 & 45 & Approved \\
\hline 8 & 92 & 94 & 38 & 35 & Approved \\
\hline 9 & 101 & 93 & 42 & 38 & Approved \\
\hline $\bar{X}$ & 103.4 & 103.5 & 42.4 & 42.3 & Approved \\
\hline
\end{tabular}
Note: $\begin{aligned} & \text { AT = Area of Triangle } \\
& \text { AK = Area of Kite }\end{aligned}$

TABLE 3. T TEST RESULT

\begin{tabular}{|c|c|c|c|c|c|c|c|c|}
\hline \multicolumn{2}{|c|}{ Variable } & $\begin{array}{c}\text { The } \\
\text { mean }\end{array}$ & $\mathbf{N}$ & \multicolumn{3}{|c|}{ Std.Deviation } & \multicolumn{2}{|c|}{$\begin{array}{c}\text { Std.Error } \\
\text { Mean }\end{array}$} \\
\hline \multicolumn{2}{|c|}{$\mathrm{X}$} & 81.13 & 32 & \multicolumn{3}{|c|}{9.154} & \multicolumn{2}{|c|}{1.618} \\
\hline \multicolumn{2}{|c|}{$\mathrm{Y}$} & 82.08 & 32 & \multicolumn{3}{|c|}{9.591} & \multicolumn{2}{|c|}{1.696} \\
\hline & \multicolumn{5}{|c|}{ Paired Differences } & \multirow[b]{3}{*}{$\mathrm{t}$} & \multirow[b]{3}{*}{ df } & \multirow{3}{*}{$\begin{array}{l}\text { Sig. } \\
(2- \\
\text { tailed) }\end{array}$} \\
\hline & \multirow[b]{2}{*}{$\begin{array}{c}\text { The } \\
\text { mean }\end{array}$} & \multirow{2}{*}{$\begin{array}{l}\text { Std } \\
\text { De } \\
\text { viat } \\
\text { ion }\end{array}$} & \multirow{2}{*}{$\begin{array}{l}\text { Std. } \\
\text { Error } \\
\text { Mean }\end{array}$} & \multicolumn{2}{|c|}{$\begin{array}{c}95 \% \\
\text { Confidence } \\
\text { Interval of the } \\
\text { Difference }\end{array}$} & & & \\
\hline & & & & Lower & $\begin{array}{l}\text { Up } \\
\text { per }\end{array}$ & & & \\
\hline$X-Y$ & $-0,938$ & $\begin{array}{r}3,9 \\
02\end{array}$ & 0.690 & $-2,344$ & $\begin{array}{r}0.4 \\
69\end{array}$ & $-1,359$ & 31 & .184 \\
\hline
\end{tabular}

The developed teaching aids have been assessed by experts and practitioners by using the questionnaire assessment dealing with the teaching aids and their instructions on how to use them. The evaluators consisted of 3 experts and 6 senior elementary school teachers who have obtained educator certificates and are teaching at elementary schools in the city of Mataram. The selected teachers are from various regions which are Ampenan, Mataram and Cakranegara. 
The teaching aid with AT code is used to develop the formula of triangle area. This aid or device is used to find out the area formula with a rectangular area approach. The assessment results for this aid showed that this device was very feasible as it obtained a TA (Teaching Aid) score = $103.4>80.3$ and an ITA (Instructions for Teaching Aid) score $42.4>33$. Further, the instructions for AT formula contain the following description:

- Students need to be reminded about the properties and elements of triangle and rectangle and the area of the rectangular area.

- Teacher shows two congruent triangle shapes such as Figure 1a, 1b and tells students to try to squeeze the two shapes together, then asks "is the area of the two buildings similar? The expected answer is that both areas are similar then the teacher asks the students to observe those elements.

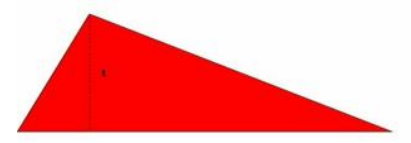

Fig.1.a Two congruent triangles

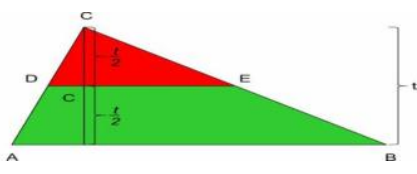

Fig.1.b Big triangle is cut into two smallas triangles

- Teacher explains that to determine the area of a triangle, the area of triangle Fig $1 \mathrm{~b}$ is cut through the midpoint of the high line and parallel to the base $(\overline{D E} / / \overline{A B})$ and it is cut off according to the line across $\mathrm{C}$ perpendicular. $\overline{D E}$
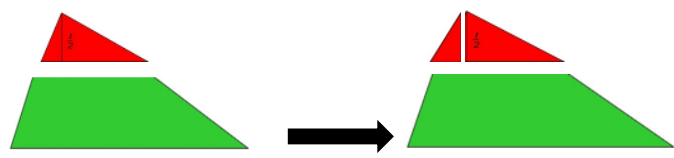

Fig.2. Two- colored triangle is cut along as illustrated, and the resulted red triangle is furter sliced along its height line.

- Teacher invites students to do an experiment that is to change the $\triangle \mathrm{ABC}$ area (as shown in Figure 4) into a rectangular $\mathrm{PQRS}$ area as follows:

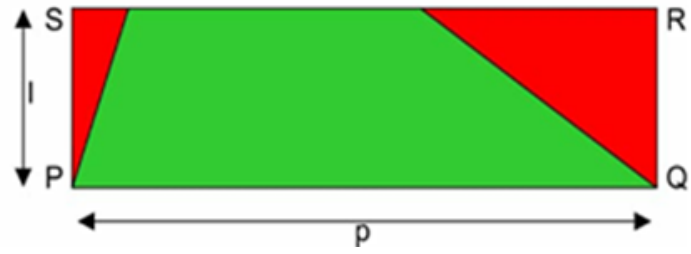

Fig.3 Sliced small triangles are put to fill the areas in the left and right of green area to create a rectangle.

- Next teacher guides students to find the relationship between the two shapes:

Base the ABC area $\triangle=$ the length of the PQRS rectangle

Area ABC height $\quad \begin{aligned} a & =p \\ \triangle & =2 \times \mathrm{PQRS} \text { rectangle width } \\ t & =2 l \\ l & =\frac{t}{2}\end{aligned}$

The area of $\mathrm{ABC}=\mathrm{p} \Delta \times l==a \times \frac{t}{2} \frac{a \times t}{2}$

Teaching aid with AK code is used to determine the formula area of the kite. The evaluation results for this tool turned out to be very feasible, because the TA score $=103.5>80.6$ and the ITA score $=42.3>33$. This indicates that the teaching aids developed have met the requirements needed, and thus, they function in teaching and learning process properly as expected [10]. The instructions within AK contain the following descriptions:

- Show an area of a kite to students and ask them about it.

- Provide the prerequisite questions by asking "what is the nature of a kite and what are its elements?" The expected answers are it has 2 diagonals and perpendicular intersection. The area of the rectangle $\mathrm{L}$ $=p \times l$

- Show 2 kites that have the same area by squeezing them as described below:
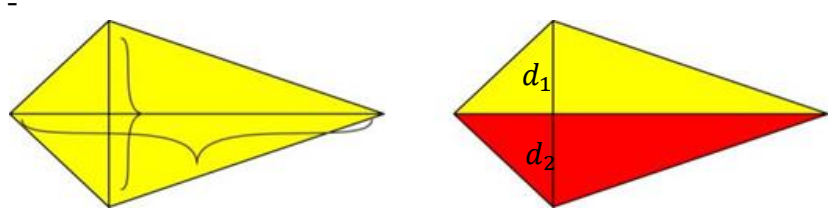

Fig 4a Two congruent kit areas Fig.4b sliced kite

- Tell students that in the kite (Figure 4) the length of the first diagonal $=d_{1}$ and the length of the second diagonal $=d_{2}$, and the kite in picture 2 will be cut to get the formula for the area of the kite.

- Cut off the kite (in Figure 4.b) according to the second diagonal so that it becomes 2 congruent triangles and cutting the red triangles according to height as follows:

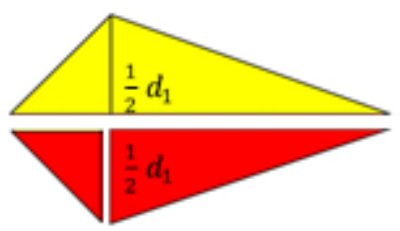

Fig. 5. A kite sliced into three areas

- $\quad$ The shape of the kite area fraction in Figure 5 will be as follows:

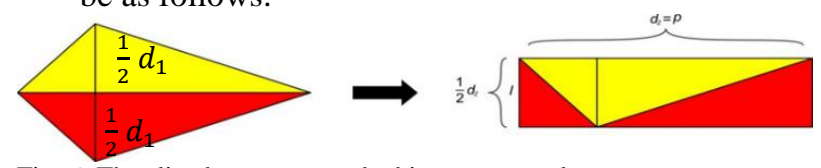

Fig. 6. The sliced areas are packed into a rectangle

- Students are guided to obtain the relationship of the elements as follow:

Kite area $=$ area of rectangular area

$=$ length $\mathrm{x}$ width $=p \times l$

$=d_{2} x \frac{1}{2} d_{1}=\frac{1}{2} d_{1} x d_{2}$

On the other hand, the results of the tryout conducted in SDN 10 for the topics of triangle and kite indicated that students in two different classes achieved the requirement 
for complete learning in which more than $85 \%$ of students have obtained a minimum learning standard score 70 and the average scores for the two classes are 81.13 and 82.06. These average scores can be categorized into very high level that the students have never achieved before. Furthermore, it was found that $\left|t_{\text {count }}\right|=1.102<t_{\text {table }}=2.042$ which means that there is no significant difference at the $5 \%$ significant level between the average scores of class A and class B when learning using the formulas of AT and AK accompanied with instructions. This indicates that the teaching aids accompanied with instructions which have been developed are consistent when used by two teachers in teaching in different classes. Overall, teaching aids in such as geometry teaching aids accompanied by instructions can make an effective learning and the teaching materials delivered by teacher to students become consistent.

\section{CONCLUSION}

This study has developed the teaching aids accompanied with instructions which can be used to determine the areas of triangle and kite. These teaching aids are very suitable for elementary school students. By providing instructions on how to use these teaching aids, the information or teaching material delivered to the students will be consistent in results even though they are used by different teachers.

For elementary school teachers who will use these teaching aids, it is advisable to have in-depth knowledge about the material they are going to teach. Mathematic teachers can change or simplify the mathematical terms to be easily understood by students however this is not to ignore the essential or the meaning of these terms. Teachers who are interested in using these teaching aids should have or explore the adequate prerequisite knowledge.

\section{REFERENCES}

[1] H. Hudoyo, "Pengembangan Kurikulum Matematika di depan Kelas," Usaha Nasional. Surabaya, 1997.

[2] N. Aisyah, "Pengembangan pembelajaran matematika SD," Jakarta: Dirjen Dikti Depdiknas, 2007.

[3] E. T. Russefendi, "Pendidikan Matematika III Modul 1-9," Depdikbud, Proy. Tenaga Kependidikan, Jakarta, 1998

[4] D. D. Asra and C. Riana, "Komputer dan Media Pembelajaran di SD," Dirjen Dikti Dep. Pendidik. Nasioanal. Jakarta, 2007.

[5] S. Kardi and M. Nur, "Pengajaran langsung," Univ. Negeri Surabaya, 2000

[6] Slameto, Belajar dan Faktor-faktor yang Mempengaruhinya. Bina Aksara, 1988.

[7] S. B. Djamarah, "Psikologi belajar." Jakarta: Rineka Cipta, 2002.

[8] K. Sarjana, "Model Penereapan Pembelajaran Kontekstual dengan Model Pengajaran Langsung dalam meningkatkan prestasi belajar pokok bahasan bilangan Bulat bagi Siswa Kelas V SD No.2 Mataram," Mataram, 2007.

[9] K. Sarjana, "Penerapan Model Van Heile berbasi CTL dalam meningkatkan prestasi belajar siswa pokok bahasan geometri bagi siswa kelas IV SD 40 Cakranegara,” Mataram, 2008.

[10]A. Sukayati \& Suharjana, "Pemanfaatan alat peraga matematika dalam pembelajaran di SD," Modul Mat. SD Progr. BERMUTU. Depdiknas PPPPTK Yogyakarta, 2009. 